\title{
FACTORS ASSOCIATED TO STUNTING IN CHILDREN AGED 6-24 MONTHS IN YOGYAKARTA
}

\author{
1 Fia Amorita Dinasty Putri, ${ }^{2}$ Nurul Qomariyah \\ ${ }^{1}$ Faculty of Public Health, Universitas Ahmad Dahlan \\ ${ }^{2}$ Faculty of Medicine, Universitas Ahmad Dahlan
}

Correspondence: n.qomariyah1501@gmail.com

Dikirim 25 Desember 2019; Diterima 27 Desember 2019; Dipublikasi Februari 2020

\begin{abstract}
Stunting is the impaired growth and development resulted from poor nutrition, repeated infection, and inadequate psychosocial stimulation. Children are defined as stunted if their height-for-age is more than two standard deviations below the WHO Child Growth Standards median. Purwomartani is a village with the highest prevalence of stunting in Kalasan (27.66\%), Sleman, Special Region Yogyakarta. The aim of the study was to determine factors that are associated with the incidence of stunting in Purwomartani. Observational analytic research was conducted with case control design. Data was taken from the Nutrition Monitoring data of Kalasan primary health center in 2018. Cases were children aged 6-24 months who experienced stunting ( $n=37)$. Control was children aged 6-24 months who are not stunted ( $n=37)$. Three respondents were excluded in each group. Total 68 data were analyzed. The results of the study showed that the majority of those who are stunted are in the age groups 13-24 months and the gender was female. Variables related to the incidence of stunting were father's education ( $O R=3.429 ; C I=1,176-9,994)$, maternal education $(O R=3,519 ; C I=1,270-9,750)$, birth weight $(O R=5,25 O ; C I=$ 1,509-18,268) and breastfeeding history $(O R=3.378 ; C I=1,246-9,157)$. Variables that were not related to the incidence of stunting are family income $(O R=1,486 ; C I=$ o,540-4,o84), maternal age $(O R=1,170 ; C I=0,390-3,512)$ and birth interval $(O R=$ 2.2750.799-6.476). Factors related to stunting were father's education, mother's education, birth weight and history of breastfeeding.
\end{abstract}

Keywords: Stunting, children aged 6-24 months, risk factors

\section{INTRODUCTION}

Stunting is the impaired growth and development resulted from poor nutrition, repeated infection, and inadequate psychosocial stimulation. Children are defined as stunted if their height-for-age is more than two standard deviations below the WHO Child Growth Standards median (1). Stunting in early life needs special attention because it can inhibit children's physical and mental development. Damage to the body and the brain caused by stunting is irreversible. Stunting children have greater possibility to grow into an unhealthy adult and at risk of non-communicable diseases (2).

The prevalence of stunting in the world is 26\%. Its prevalence in South Asia is $39 \%$, whereas in Eastern Africa is $40 \%$. Indonesia is the fifth country in the world with stunting after India, Nigeria, Pakistan and China (3). Nationally, the prevalence of stunting is $37.2 \%$. It consists of $18.0 \%$ very short and $19.2 \%$ short. 
The data showed, the stunting prevalence in 2010 (35.6\%) increased by $1.6 \%$ compared to 2007 (36.8\%). In Indonesia, the prevalence of stunting (height/ age) in children under five years old is higher than the prevalence of underweight or poor nutrition (weight/ age) (19.6\%) and the prevalence of wasting or thin (weight / height) (5.3\%) (4).

Stunting is caused by several interrelated factors. There are five cluster: maternal nutrition and infection, teenage motherhood and short birth intervals, fetal growth restriction (FGR) and preterm birth, child nutrition and infection, and environmental factors (5). Children with no exclusive breastfeeding have 6.54 more times become stunting compared to children with exclusive breast feeding (6). Fajrina study in 2016 showed that there is relationship between mother's age during pregnancy and birth interval with stunting. The study stated that mother who are $<20$ years and $>35$ years have 4.08 more times to have children with stunting (7). Another factors such as parent's education and family income contribute to the incidence of stunting. These two factors influence family eating behavior (8.9).

Data from ministry of health, Indonesia showed that Sleman Regency is a district with the second largest stunting prevalence in Yogyakarta after Gunung Kidul Regency (10). Kalasan primary health center, in Sleman regency, Yogyakarta province, Indonesia is a primary health center with the highest prevalence of stunting in Sleman regency. Prevalence data in Kalasan primary health center in 2015 showed that 809 children under five years old (20.87\%) are stunting and the number increased to $22,30 \%$ in 2016. One of the four villages in Kalasan is Purwomartani vilage with the highest prevalence of stunting, which is $27.66 \%$ (11).

The first 1.000 days of life since the womb is a window of opportunity which determine whether the child will be stunting or not. Many stunting children are found in the first two years of life ( $<24$ months) (2). Stunting will be a problem for the community if its prevalence is 20\% (12). Stunting prevalence in Kalasan

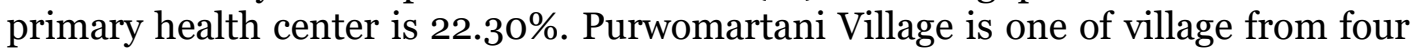
villages in the working area of Kalasan primary health center with the highest number of stunting. Previous studies conducted in several different places in Indonesia, did not explore the role of fathers on stunting incidence. It is important to explore factors related to stunting in children age 6-24 months from both factors of father and mother in Purwomartani village. The result of the study will be the important information for the health workforces to reduce stunting in Purwomartani village.

\section{METHOD}

The design of this study is observational analytic using case control design. The location of the study is in Purwomartani village, Kalasan district, Sleman regency, Yogyakarta province, Indonesia. Case is stunting children aged 6-24 months who have lived in Purwomartani Village, Kalasan District, Sleman Regency. The number of stunting children in this Purwortani village were taken from data of Nutrition Status Monitoring (penentuan status gizi/PSG) of Kalasan Primary Health Center in February 2018. The sample in this study was taken by total sampling technique. There were 37 stunting children. Control group is children aged 6-24 months who are not stunting and the closest neighbor to the children in case group. Comparison between number of cases and the number of controls is $1: 1$ so the number in each group were 37 children.

Research samples must meet inclusion and exclusion criteria. Inclusion criterias for case group are stunting, aged 6-24 months old, registered at Kalasan Primary Health Center in February 2018, reside in Purwomartani Village, Kalasan District, Sleman Regency and can be found at home at the time of the study after 3 
visits. Inclusion criterias for control group are normal children aged 6-24 months old, reside in Purwomartani Village, Kalasan District, Sleman Regency and can be found at home at the time of the study after 3 visits.

Exclusion criterias for case and control groups are suffering from mental and physical disorders, and experiencing infectious disease. Total sampling technique was used in this study. Thirty-seven stunting children in case group and 37 children in control group, with comparison $1: 1$. The researcher visit the respondent in their house.

\section{RESULTS AND DISCUSSION}

Purwomartani Village is one of the villages in the region Kalasan District, Sleman Regency with an area of 1.205.0OOO Ha. The administrative area of Purwomartani Village consists of 21 Hamlets. The height of Purwomartani region is at $\pm 127 \mathrm{~m}$ altitude from sea level with an average rain fall of $2.000 \mathrm{~mm}$ / year, as well the average temperature per year is $30-33^{\circ} \mathrm{C}$.

Based on data of Governance Bureau, Regional Secretariat of Yogyakarta Special Region (Biro Tata Pemerintahan Setda DIY) (2018): total population in Purwomartani village is 34.322 with balanced ratio between male and female; 42.3\% population is in productive age (20-59 years old); only less than $10 \%$ of population graduates from university; and majority of the population are working in private sector (13).

Three respondents from case group were excluded because they did not live in Purwomartani village anymore. Total data from 68 respondents (@34 respondents from case and control group) were analyzed. Demographic data showed that majority of children with stunting were in aged 13-24 months (72,06\%). While more than half of children with stunting were female $(52,94 \%)$. Detail of univariate analysis can be seen in Table 1 and 2.

Table 1. Frequency distribution of children aged 6-24 months based on age and sex in Purwomartani Village, Kalasan District, Sleman Regency

\begin{tabular}{lcc}
\hline \multicolumn{1}{c}{ Variables } & Frequency (n) & Percentage (\%) \\
\hline Age & & \\
\hline 6-12 months & 19 & 27,94 \\
\hline 13-24 months & 49 & 72,06 \\
\hline Sex & & \\
\hline Male & 32 & 47,06 \\
\hline Female & 36 & 52,94 \\
\hline
\end{tabular}

Majority of respondents have high level of father's education $(72,06 \%)$ and mother's education (52,94\%); high level of family income $(68,18 \%)$; were born from mother with age that is not risky (75\%); have safe birth interval $(67,65 \%)$; have normal birth weight $(58,82 \%)$ and have experiences of exclusive breastfeeding $(52,94 \%)$. 
Table 2. Frequency distribution of children's family in Purwomartani Village, Kalasan District, Sleman Regency

\begin{tabular}{|c|c|c|c|c|c|c|c|}
\hline No & Variables & $\begin{array}{c}\text { Frequency } \\
\text { (n) }\end{array}$ & $\begin{array}{c}\text { Percentage } \\
(\%)\end{array}$ & No & Variables & $\begin{array}{c}\text { Frequency } \\
\text { (n) }\end{array}$ & $\begin{array}{c}\text { Percentage } \\
(\%)\end{array}$ \\
\hline \multirow[t]{3}{*}{1} & Father's education & & & \multirow[t]{3}{*}{5} & Birth interval & & \\
\hline & Low & 45 & 66,18 & & $<36$ months & 22 & 32,35 \\
\hline & High & 23 & 33,82 & & $>36$ months & 46 & 67,65 \\
\hline \multirow[t]{3}{*}{2} & Mother's education & & & \multirow[t]{3}{*}{6} & Birth weight & & \\
\hline & Low & 40 & 58,82 & & Risky & 18 & 41,18 \\
\hline & High & 28 & 41,18 & & Not risky & 50 & 58,82 \\
\hline \multirow[t]{3}{*}{3} & Family income & & & \multirow[t]{3}{*}{7} & Breastfeeding $\mathrm{l}$ & & \\
\hline & Low & 23 & 33,82 & & Risky & 32 & 47,06 \\
\hline & High & 45 & 68,18 & & Not risky & 36 & 52,94 \\
\hline \multirow[t]{3}{*}{4} & Mother's age & & & & & & \\
\hline & Risky & 17 & 25,00 & & & & \\
\hline & Not risky & 51 & 75,00 & & & & \\
\hline
\end{tabular}

Bivariate analysis using chi square test with the level of confidence 95\% $(\mathrm{p}=0,05)$ was done to evaluate the relationship between several variables with stunting. Odds Ratio (OR) was used to measure the power of the relationship between variables with the incidence of stunting. The result shows that there are several variables which show statistically relationship with stunting, namely: father's education ( $\mathrm{p}$ value $=$ o,040; OR = 3.429; $\mathrm{CI}=1,176-9,994)$, maternal education ( $\mathrm{p}$ value $=0,027 ; \mathrm{OR}=$ 3,$519 ; \mathrm{CI}=1,270-9,750$ ), birth weight ( $\mathrm{p}$ value $=0,013 ; \mathrm{OR}=5,250 ; \mathrm{CI}=1,509-18,268$ ) and breastfeeding history ( $\mathrm{p}$ value $=0,029 ; \mathrm{OR}=3.378 ; \mathrm{CI}=1,246-9,157$ ). Detail of the result is provided in Table 3 .

Table 3. Relationship between variables with stunting in children aged 6-24 months in Purwomartani Village, Kalasan District, Sleman Regency

\begin{tabular}{|c|c|c|c|c|c|c|c|c|c|c|}
\hline \multirow[b]{2}{*}{ No } & \multirow[b]{2}{*}{ Variables } & \multirow[b]{2}{*}{ Categories } & \multicolumn{2}{|c|}{ Case } & \multicolumn{2}{|c|}{ Control } & \multicolumn{2}{|c|}{ Total } & \multirow{2}{*}{$\begin{array}{c}\mathrm{P} \\
\text { value }\end{array}$} & \multirow{2}{*}{$\begin{array}{c}\text { OR } \\
(95 \% \\
\text { CI })\end{array}$} \\
\hline & & & $\mathrm{n}$ & $\%$ & $\mathrm{n}$ & $\%$ & $\mathrm{n}$ & $\%$ & & \\
\hline \multirow[t]{3}{*}{1} & \multirow{3}{*}{$\begin{array}{l}\text { Father's } \\
\text { education }\end{array}$} & Low & 27 & 79,41 & 18 & 52,94 & 45 & 66,18 & \multirow{3}{*}{$\mathbf{0 , 0 4 0}$} & \multirow{3}{*}{$\begin{array}{l}\mathbf{3 , 4 2 9} \\
(1,176- \\
9,994)\end{array}$} \\
\hline & & High & 7 & 20,59 & 16 & 47,06 & 23 & 33,82 & & \\
\hline & & Total & 34 & 100,00 & 34 & 100,00 & 68 & 100,00 & & \\
\hline \multirow[t]{3}{*}{2} & \multirow{3}{*}{$\begin{array}{l}\text { Mother's } \\
\text { education }\end{array}$} & Low & 25 & 73,53 & 15 & 44,12 & 40 & 58,82 & \multirow[t]{3}{*}{$\mathbf{0 , 0 2 7}$} & \multirow{3}{*}{$\begin{array}{c}\mathbf{3 , 5 1 9} \\
(1,270- \\
9,750)\end{array}$} \\
\hline & & High & 9 & 26,47 & 19 & 55,88 & 28 & 41,18 & & \\
\hline & & Total & 34 & 100,00 & 34 & 100,00 & 68 & 100,00 & & \\
\hline \multirow[t]{3}{*}{3} & \multirow{3}{*}{$\begin{array}{l}\text { Family } \\
\text { income }\end{array}$} & Low & 13 & 38,24 & 10 & 29,41 & 23 & 33,82 & \multirow[t]{3}{*}{0,608} & \multirow{3}{*}{$\begin{array}{c}1,486 \\
(0,540- \\
4,084) \\
\end{array}$} \\
\hline & & High & 21 & 61,76 & 24 & 70,59 & 45 & 66,18 & & \\
\hline & & Total & 34 & 100,00 & 34 & 100,00 & 68 & 100,00 & & \\
\hline \multirow[t]{3}{*}{4} & \multirow[t]{3}{*}{ Mother's age } & Risky & 9 & 26,47 & 8 & 25,53 & 17 & 25,00 & \multirow[t]{3}{*}{1,000} & \multirow{3}{*}{$\begin{array}{c}1,170 \\
(0,390- \\
3,512) \\
\end{array}$} \\
\hline & & Not risky & 25 & 73,53 & 26 & 76,47 & 51 & 75,00 & & \\
\hline & & Total & 34 & 100,00 & 34 & 100,00 & 68 & 100,00 & & \\
\hline \multirow[t]{3}{*}{5} & \multirow[t]{3}{*}{ Birth interval } & $<36$ months & 14 & 41,18 & 8 & 23,53 & 22 & 32,35 & \multirow{3}{*}{0,195} & \multirow{3}{*}{$\begin{array}{c}2,275 \\
(0,799- \\
6,476) \\
\end{array}$} \\
\hline & & $>36$ months & 20 & 58,82 & 26 & 76,47 & 46 & 67,65 & & \\
\hline & & Total & 34 & 100,00 & 34 & 100,00 & 68 & 100,00 & & \\
\hline \multirow[t]{3}{*}{6} & \multirow[t]{3}{*}{ Birth weight } & Risky & 14 & 41,18 & 4 & 11,76 & 18 & 26,47 & \multirow{3}{*}{$\mathbf{0 , 0 1 3}$} & \multirow{3}{*}{$\begin{array}{c}\mathbf{5 , 2 5 0} \\
(1,509- \\
18,268) \\
\end{array}$} \\
\hline & & Not risky & 20 & 58,82 & 30 & 88,24 & 50 & 73,53 & & \\
\hline & & Total & 34 & 100,00 & 34 & 100,00 & 68 & 100,00 & & \\
\hline 7 & Breastfeeding & Risky & 21 & 61,76 & 11 & 32,35 & 32 & 47,06 & 0,029 & $\mathbf{3 , 3 7 8}$ \\
\hline & history & Not risky & 13 & 38,34 & 23 & 67,65 & 36 & 52,94 & & $(1,246-$ \\
\hline & & Total & 34 & 100,00 & 34 & 100,00 & 68 & 100,00 & & 9,157) \\
\hline
\end{tabular}


Bivariate analysis shows that father's education has relationship with stunting $(\mathrm{p}$ value $=0,040)$. Another study, showed the relationship between father's education with stunting $(p=0,036)$. The study showed that children with less educated father have 2,224 more likely become stunting (10). Based on the experience of researcher experiences during interview and observation in Purwomartani village, many fathers are focused as the source of income for the family. Those type of fathers are not well involved in childcare at home, so there will be less parenting support to the mothers. Odds Ratio (OR) was used to measure the power of the relationship between variables with the incidence of stunting. The result shows that there are several variables which show statistically relationship with stunting, namely: father's education ( $\mathrm{p}$ value $=0,040 ; \mathrm{OR}=$ 3.429; $\mathrm{CI}=1,176-9,994)$, maternal education ( $\mathrm{p}$ value $=0,027 ; \mathrm{OR}=3,519 ; \mathrm{CI}=$ $1,270-9,750$ ), birth weight ( $\mathrm{p}$ value $=0,013$; OR $=5,250 ; \mathrm{CI}=1,509-18,268$ ) and breastfeeding history ( $\mathrm{p}$ value $=0,029 ; \mathrm{OR}=3.378 ; \mathrm{CI}=1,246-9,157$ ).

UNICEF (2002) stated that children need attention and care from both of their parents, not merely only from their mother. Both parent, father and mother have the same responsibilities in parenting. Father could be the arbiter in parenting and in breastfeeding as well (17). Father's behaviour could give an important impact to the eating, physical activity's behaviour and another health outcome to their children(18). Another study found that there was a close relationship between father's education and height changes in children who are found stunting in aged 6-12 months. Those children were free of stunting in aged 3-4 years (19). Father's education affects children's health indirectly, by its role in determining family income (20).

Usually father's education level relating to household income. If the father is more educated, they usually get more money. Fathers with low education tend to find difficulties to have a job with a better income. This causes the family's income allocated in purchasing foodstuffs is reduced, consequently children experience malnutrition and become stunting.

Bivariate analysis in Table 3 shows there is relationship between mother's education and stunting ( $\mathrm{p}$ value $=0,028$ ). Based on the theory, the level of formal education has close relationship with amount of the knowledge. Someone with lower formal education, will find more difficulties in understanding the knowledge related to children nutrition. Based on the researcher experiences during interview and observation in Purwomartani village, many mothers do not know the impact of stunting and lack of understanding in exclusive breastfeeding. Many mothers feed their children solely based on child preference without considering some aspects as the nutrition content in the food, the child nutritional needs, and traditional practice by giving honey to the neonates. The level of the nutrition understanding influences the attitude and behaviour in food choosing. People with less knowledge on nutrition will choose the food based on the interest of the sense organs without considering the nutritional content $(21,22,23)$.

Birth weight is one of the risk factors of stunting (24). The study conducted in India showed that children with low birth weight (LBW) have 1.82 more likely become stunting compared to the children with normal birth weight at the same age (25). The other study showed that birth weight had direct influence on stunting. Cohort perspective study in Cebu, Philippine and Ethiopia in children aged 12 months showed that the stunting prevalence is significantly higher on infant with LBW [26]. Infant with LBW is more likely become stunting compared to the infant with normal birth weight. Infant with LBW is more risk on health 
problems and growth delayed. LBW influences children development and health related problems to the child in the future (27).

Based on the interview and observation from 18 respondents with LBW, majority of the case is caused by premature birth. One of the factors influence the premature birth is the poor nutritional status of the mother. UNICEF stated that mother with poor nutritional status has greater opportunity to have baby with LBW compared to mother with normal nutritional status. Fetus with poor nutrition in the womb also has greater opportunity to become stunting $(3,28,30)$.

The result of this study also showed the relationship between history of breastfeeding with stunting. The study showed that children with no exclusive breastfeeding have 3,378 more likely become stunting compared to the children with exclusive breastfeeding. Exclusive breastfeeding is the best food for children aged o- 6 months. No additional liquid and solid food are required in exclusive breastfeeding (ex. formula milk, orange juice, honey, tea, and mineral water, banana, porridge, etc). Children with exclusive breastfeeding have better nutritional status compared to children with no exclusive breastfeeding (31). Several factors are identified as barrier of exclusive breastfeeding, namely: early feeding with solid food to the infant $<6$ months and delayed breastmilk production because of mother's emotional stress (32).

The other variables in this study such as family income, mother's age, and birth interval showed no relationship with the incidence of stunting in Purwomartani village. The health workforce in Kalasan primary health care can focused on the identified risk factors that were found in this study. Clear and systematic efforts have to be done by health sectors and other related sectors such as education sector to increase knowledge, attitude, and behavior of the community to solve problems of stunting in working area of Kalasan primary health care and other region with the same context.

\section{CONCLUSION}

Factors related to stunting in children aged 6-24 months in Purwomartani village were father's education, mother's education, birth weight and history of breastfeeding.

\section{REFERENCES}

1. World Health Organization (WHO). Stunting in nutshell. Nutrition. 2019. Available https://www.who.int/nutrition/healthygrowthproj stunted videos/en/

2. UNICEF. Ringkasan Kajian Gizi. 2012. Available at: http://www.unicefindonesia.org

3. UNI CEF. Improving Child Nutrition. The achievable imperative for global progress. 2013. Available at: http://www.unicef.org.

4. Depkes RI. 2013. Riset Kesehatan Dasar (RISKESDAS). Available at: http://www.depkes.go.id

5. Danaei G, Andrews KG, Sudfeld CR, Fink G, McCoy DC, Peet E, et al. Risk Factors for Childhood Stunting in 137 Developing Countries: A Comparative Risk Assessment Analysis at Global, Regional, and Country Levels. 2016. PLoS Med 13(11): e1002164. doi:10.1371/journal.pmed.1002164

6. Lestari, W., Margawati, A., Rahfiludin, Z. Faktor Risiko Stunting Pada Anak Umur 6-24 Bulan Di Kecamatan Penanggalan Kota Subulussalam Provinsi Aceh. Jurnal Gizi Indonesia. 2014. Vol. 3, No 1: 37-45. 
7. Fajrina, Nurul. Hubungan Faktor Ibu Dengan Kejadian Stunting Pada Balita Di Puskesmas Piyungan Kabupaten Bantul. 2016. Available at: http:// www.digilib.unisajogja.ac.id

8. Adriani, M. \& Wirjatmadi, B. Gizi dan Kesehatan Balita. Jakarta: Kencana Prenademia Group. 2014.

9. Ngaisiyah, Dewi. Hubungan Sosial Ekonomi Dengan Kejadian Stunting Pada Balita Di Desa Kanigoro, Saptosari, Gunung Kidul. 2015. Jurnal Medika Respati Vol X Nomor 4. http://medika.respati.ac.id.

10. Kemkes RI. Ringkasan Eksekutif Data dan Informasi Kesehtan Provinsi D.I Yogyakarta. 2016. Available at: http://www.pusdatin.kemkes,go.id.

11. Puskesmas Kalasan. Data Pemantauan Status Gizi (PSG) tahun 2017

12. World Health Organization (WHO). Nutrition Landscape Information System (NLIS)

Country Profile Indicators: Interpretation Guide. Geneva: WHO, 2010.

13. Governance Beureu (Biro Tata) Pemerintahan Setda DIY. Jumlah Penduduk Kota Yogyakarta Semester I 2018, Biro Tata Pemerintahan Setda DIY. http://kependudukan.jogjaprov.go.id,

14. Girma W \& Genebo T. Determinants of the Nutritional Status of Mothers and Children in Ethiopia. ORC Macro, Calverton, Maryland, USA. 2002.

15. Hafid, fahmi dan Nasrul. Faktor Risiko Stunting pada Anak Usia 6-23 Bulan di Kabupaten Jeneponto. indonesian Journal of Human Nutrition, 2016. Vol.3 No.1Hal:42-53.

16. Eunice, A., dan Sarah, D. An assestment of nutritional status of under five children in four district in the central religion of Ghana. Asian Journal of Agriculture and Rural Development. 2013. vol 3, 851-860

17. Engle, P.L., P. Menon, L. Haddad. Care and Nutrition: Concepts and Measurement. International Food Policy Research Institute. 1997.

18. Walsh $\mathrm{AD}$, Hesketh $\mathrm{KD}$, van der Pligt $\mathrm{P}$, Cameron AJ, Crawford D, Campbell KJ. "Fathers' perspectives on the diets and physical activity behaviours of their young children”. Journal Pone. 2017. Vol 12 No 6.

19. Rahayu L.S, Sofyaningsih M. Pengaruh BBLR (Berat Badan Lahir Rendah) dan Pemberian ASI Eksklusif Terhadap Perubahan Status Stunting Pada Balita di Kota

dan Kabupaten Tangerang Provinsi Banten. Prosiding Seminar Nasional "Peran Kesehatan Masyarakat dalam Pencapaian MDG's di Indonesia”; 12 April 2011

20. Mosley WH, Chen LC. Suatu Kerangka Analisis untuk Studi Kelangsungan Hidup Anak di Negara Berkembang, Terjemahan Masri Singarimbun. Gajahmada

University Press. Yogyakarta. 1984.

21. Kusuma, K. E., Nuryanto, N. "Faktor Risiko Kejadian Stunting Pada Anak Usia 2-3 Tahun (Studi di Kecamatan Semarang Timur)". Journal of Nutrition College, 2013.Vol 2, No 4 .

22. Sediaoetama, Achmad Djaeni. Ilmu Gizi untuk Mahasiswa dan Profesi Jilid 1. Cetakan Kesepuluh. Jakarta: Dian Rakyat. 2012.

23. Khomsan. A., Sukandar, Dadang. "Perception of mother's and childrend's participation in the national programs". Jurnal gizi dan pangan 2007. Vol 2 No 2 Hal: 26-35.

24. Saaka, Mahama., Galaa, Sylvester Zackaria. Relationships between Wasting and Stunting and Their Concurrent Occurrence in Ghanaian Preschool Children.

Journal of Nutrition and Metabolisme. 2016. 
25. Upadhyay, Ashish K, and Srivastava S. Effect of Pregnancy Intention, Postnatal Depressive Symptoms and Social Support on Early Childhood Stunting:

Findings from India. BMC Pregnancy and Childbirth. 2016.

26. Neupane S, Nwaru BI. "Impact of prenatal care utilization on infant care practices in Nepal: a national representative cross-sectional survey". Journal Pediatri. 2014. 173(1):99-109. doi: 10.1007/s00431-013-2136-y.

27. Depkes RI. INFODATIN Pusat Data dan Informasi Kementrian Kesehatan Situasi Balita Pendek. 2016. http://www.pusdatin.kemkes.ac.id.

28. Supariasa, D. Dkk. Penilaian Status Gizi. Penerbit Buku Kedokteran EGC: Jakarta. 2002.

29. Barker D. J. P. The origins of the developmental origins theory.Journal of Internal Medicine. 2007 Volume 261, Issue5 Pages 412-417.

30. Giri, M.K.W., Muliarta, I.W., Wahyuni, N.P.D. Hubungan pemberian asi eksklusif dengan status gizi balita usia 6-24 bulan di Kampung Kajanan, Buleleng. Jurnal Sains dan Teknologi, 2013. 2(1), 184-192.

31. Nurastrini, VR.,Kartini A. Jenis Mp-Asi, Frekuensi Dan Waktu Pertama Kalipemberian Mp-Asi Sebagai Faktor Risiko Kejadian Gizi Lebih Pada Bayi Usia 6-12 Bulan Di Kota Magelang Ournal Of Nutrition College, Volume 3, Nomor 1, Tahun 2014, Halaman 259-265. 